\title{
GENOTOXICITY IN CHIRONOMUS KIIENSIS (CHIRONOMIDAE: DIPTERA) AFTER EXPOSURE TO POLLUTED SEDIMENTS FROM RIVERS OF NORTH PENINSULAR MALAYSIA: IMPLICATION FOR ECOTOXICOLOGICAL MONITORING
}

\author{
SALMAN A. AL-SHAMI ${ }^{\mathrm{a}}$, CHE SALMAH MD RAWI ${ }^{\mathrm{a}}$, SITI AZIZAH MOHD NOR ${ }^{\mathrm{a}, \mathrm{b}}$, ABU HASSAN AHMAD $^{\mathrm{a}}$, \\ NUR ADIBAH MOHD ISHADI ${ }^{\mathrm{a}}$ and HAMADY DIENG ${ }^{\mathrm{a}}$ \\ ${ }^{a}$ School of Biological Sciences, Universiti Sains Malaysia, Penang Malaysia \\ ${ }^{\mathrm{b}}$ Centre for Marine and Coastal Studies, Universiti Sains Malaysia, Penang Malaysia
}

\begin{abstract}
Rapid industrialization and urbanization has led to increasing input of chemical contaminants into the aquatic environment of Malaysia. Despite the threat civilization poses to the biota, there are still very few relevant studies on ecotoxicological testing of river ecosystems. To overcome this knowledge gap, we examined lethal and genotoxic effects of sediments from different rivers of the northern Malaysia against Chironomus kiiensis, a group well represented in the aquatic fauna of this region. We exposed the larvae to sediments from Selama River (SR), Permatang Rawa River (PRR) and Kilang Ubi River (KUR) at various durations $(0,6,12,24$ and $48 \mathrm{~h})$. The larval mortality was monitored, whereas DNA damage in survivors' cells was determined using the comet assay. Pollution level indexed by the amounts of heavy metals and other organic contaminants in the sediment showed progressive increases from SR to PRR to KUR. Highly polluted sediments (PRR to KUR) were detrimental to C. kiiensis larvae, most of which did not survive following exposure for long periods. DNA analyses revealed greater damages in nuclei derived from larvae maintained on polluted sediments, in particular, those from KUR. The effects on the genomic material of $C$. kiiensis larvae occurred in a timedependent manner, with damage level increasing as exposure time progressed. Our results highlight the genotoxic properties of polluted sediments. More importantly, this study showed that $C$. kiiensis larvae could respond to different levels of pollution with respect to exposure time. It is concluded that $C$. kiiensis larvae is a potential candidate for river ecotoxicological monitoring. Copyright (c) 2012 John Wiley \& Sons, Ltd.
\end{abstract}

KEY WORDS: chironomids; heavy metals; Juru River; genotoxicity; sediments

Received 25 May 2011; Revised 9 May 2012; Accepted 10 June 2012

\section{INTRODUCTION}

The pollution of aquatic ecosystems has emerged as a major ecological problem, worldwide. Like many other countries, Malaysia is facing severe water pollution problems. Several rivers are heavily polluted with pesticides, organic wastes, metallic elements (DOE, 1994), and domestic as well as land-based activities (Azrina et al., 2006, Yap et al., 2008). In the northern part of the country, sediments of the Juru River are now heavily polluted with heavy metals such as $\mathrm{Cd}, \mathrm{Cu}$, $\mathrm{Pb}$ and $\mathrm{Zn}$ (Lim and Kiu, 1995; Al-Shami et al., 2011a). These contaminants are most likely discharges from industrial premises of Prai, where many light and heavy industries are present (Mat and Maah, 1994).

River sediments have long been recognized as a sink for inorganic contaminants as well as heavy metals, which affect the inhabitant benthic community (Lewis and Galloway, 2008). Sediments contaminated with heavy metals can damage DNA either directly or indirectly via the production

*Correspondence to: S. A. Al-Shami, School of Biological Sciences, Universiti Sains Malaysia (USM), 11800 Penang, Malaysia.

E-mail: alshami200@gmail.com of free radicals or after metabolic activation (Haldsrud and Krokje, 2009; Lacaze et al., 2010). It is well documented that sediment-borne pollutants have the potential to cause DNA damage in aquatic biota (Chen and White, 2004; Kosmehl et al., 2008). Many genotoxic chemicals have been identified in sediments (Kilemade et al., 2004; Kosmehl et al., 2008; Rocha et al., 2009) and urbanized water (Rigonato et al., 2010), which unfortunately may be remobilized to the free water phase via bioturbation (Power and Chapman, 1992) and flood events (Hollert et al., 2000).

Sediment-dwelling organisms (benthos) are important carriers of sediment-associated contaminants to higher trophic levels in the food web because they form the primary food source for many commercial fish and crustacean species. Understanding and monitoring the genotoxic impacts of pollutants in benthic organisms is therefore of great importance for both the environment and human health (Lewis and Galloway, 2008). In Malaysia, few aquatic invertebrates were applied to monitor the environmental health and water quality. For instance, marine organisms including green lipped mussel Perna viridis and mudflat snail Telescopium telescopium have been applied as bioindicators for heavy meals contamination in sediments (Yap et al., 2003; Yap et al., 2006a, 2006b; 